\title{
Evaluating the Economic Impact of the E-Government Project Analytical Study on the E-Government Initiative in Syria
}

\author{
Ahmad Juratli \\ Hungarian University of Agriculture and Life Sciences, \\ Gödöllő u. 1, 2100, Hungary
}

\section{A B S T R A C T}

This study aimed to introduce the importance of implementing the e-government project in general and in Syria in particular, in addition to clarifying the economic impact on the implementation of this strategic project, and thus clarifying the necessity of financing and directing this project. Accordingly, the study used the most important recent periodic government reports issued by the government regarding the implementation of this project. This paper relied on an analytical approach whereby the economic impact of e-government was analyzed in general, and then the same effect was studied on the Syrian side, and the study took into account the analysis of the return based on value. The study showed that e-government initiatives improve labor productivity in the public sector, provide meaningful services, save costs, and achieve growth in GDP. The study also confirmed that the application of e-government has a positive impact on the Syrian economy by studying the return both on the government as an implementing agency or the citizen as a beneficiary. Syria is currently going through a transitional phase and economic progress and is striving for success. This requires re-engineering the infrastructure and managing all official bodies that deal with beneficiaries through the application of e-government in most of its institutions, and based on the results of this study, future analytical studies must be conducted. About statistical analysis to know the impact of implementing the e-government project inside the institutions on the beneficiary citizens and the

\section{AR T I C L E I N F O}

Article History:

Received : 15-01-2021

Revised : 24-03-2021

Accepted : 23-04-2021

Published : 30-06-2021

Keywords:

E-government (EG)

Economic Impact

Syria

JEL: A1, M10, M15 
performance of employees. Accordingly, this study provides a methodology for analyzing the financial and economic benefits of projects within the e-government strategy. This paper helps shed light on the goals of e-government and spread public awareness as a result of implementing this project and show its economic impact. Also, this study is valuable for researchers as an input for future research.

*Corresponding Author E-mail: ahmadrjf@hotmail.com

Copyright (C) 2021 Authors. This is an open access article distributed under the Creative Commons Attribution License (CC-BY-SA 4.0) which permits use, distribution and reproduction in any medium, provided the original work is properly cited \& ShareAlike terms followed.

\section{INTRODUCTION}

The e-government project is considered one of the most important strategic projects in the world. Most countries of the world realized that the application of electronic programs serve as the economic and administrative lever, and all experiences emphasized the importance of this project and its positive impact on all aspects of life. This study tries to present the importance of implementing the e-government project in the case of Syria. And to show its economic impact even in the early stages, thus showing the extent of the economic feasibility of the project, as well as encouraging investments related to this certain e-government implementation and financing the project by the state and the funding agencies.

Through practical studies, official reports and UN permits the initiative to implement the egovernment program in Syria, the study adopted and considered it as the preliminary basis to highlight the government's goals in spreading and increasing public awareness as a result of the application of the e-government and its economic impact.

Currently, Syria is in the process of moving towards economic revival and is striving for success, and this will require re-engineering of the infrastructure and administration of all official bodies that deal with the beneficiaries.

The start of the e-government project is the real initiative to raise the efficiency of public institutions and their employees and a basic motivation to reduce expenditures, reduce the cost of government tasks and save the time of delivering services to the citizens. All of this can be achieved in Syria due to the availability of financial and human resources that contribute to strengthening the infrastructure of the communications and information technology sector, and this is one of the factors and principles that determine the level of success of this project. With a vision similar to most countries that have implemented the egovernment programs, and based on the initial reports and surveys in Syria, the following goals can be expected to be achieved by implementing the e-government project in Syria: (United Nations Development Program UNDP, 2011).

- Increasing job opportunities related to the business sector and citizen services.

- Reducing the cost in the institutions in terms of providing services, in addition to raising the efficiency of institutions.

- Reducing the time and cost of interacting with the government on more than one level: government-citizens (G2C), governmentbusiness sector (G2B), governmentgovernment (G2G), in addition to reducing the time and cost of government-togovernment interaction with other governments.

- Raise the level of transparency in dealing between the government and the beneficiaries or all types of users according to one parity. 
Regarding how to measure the impact of implementing e-government programs, this matter can be determined through multiple indicators such as the number of transactions executed electronically and comparing them with transactions executed on paper, speed of implementation, cost before implementation, and after implementation for the citizen or government.

\section{Problem Statement}

For strategic goals and economic reasons, the project of implementing e-government in Syria has become necessary in order to be in line with the requirements of the next stage and with other countries, which made Syria actively seek to move towards the application of e-government in the general government sector, as an emphasis on success, to the stage of economic recovery, Implementing this project requires re-engineering the infrastructure and administration of all official bodies that deal with beneficiaries.

From the foregoing, and under the auspices of e-government programs in the business sector, the transition from the traditional stage of commerce to the business sector will take place electronically through electronic commerce. This matter will enhance interaction between government agencies, as well as interaction with the beneficiaries, through the flexibility of services provided and directed to the business sector. From here, the research problem became clear and the study sought to answer the following question: Is there an economic impact of applying e-government in Syria?

\section{Research Objective}

Through the economic feasibility of the egovernment project in Syria as a strategic project, the importance of this study appears. In addition to the positive economic impact on the overall economy since the early stages of implementation, there is also another important matter that made it very necessary to finance this strategic project and direct investments to this project, and this study accordingly is sought to fulfill this purpose. It is aimed to build an analytical vision on the expected financial and economic benefits as a result of implementing the e-government project in Syria, to determine its feasibility, and to indicate the expected effects on the overall economy.

\section{Significance of the Research}

The importance of the research stems from the important role of the e-Government itself as it will have the basic role in the reconstruction phase in Syria after many years of suffering because of the local wars since 2011, encourage of electronic development was the main factor to support the initiative of Government and finally to start in implementing the project, with taking in the consideration the following aspects that show the importance of this research paper:

- Analysing the economic impact after implementing e-government programs.

- Cost-benefit analysis (CBA) from implementing e-government.

\section{LITERATURE REVIEW}

\section{E-government Maturity Mode}

The exploitation of the resources and services required to implement the e-government project is the first stage towards maturity through interaction and harmony between the concerned authorities in addition to the interaction of citizens and coordination with intermediary government agencies with the administrative institutions that ultimately contribute to:

- Increasing business sector development opportunities (with direct, indirect and implicit contributions) and citizen services.

- Increasing the production efficiency of government institutions by reducing the costs of practicing public administration for their activities that they used to traditionally carry out.

- $\quad$ Raising the level of transparency and treat users equally.

- Reducing the time and costs of interacting with the government according to the egovernment models: government-citizens (G2C), government-business sector (G2B), government-government (G2G), including government interaction with the public 
sector and with the governments of other countries. (Palvia \& Sharma, 2007)

The experiences in many countries that have implemented the project indicate that the first stage begins after formulating the policies, which is the dissemination of information and the uploading of users' requests electronically (Krishnan, Teo, \& Lymm, 2017). This stage focuses on the providers of technical services and then moves to the second and third stage, which includes interactive processes between the parties that request the service from the government with all its institutions, then the final fourth phase that revolves around the government's concerns towards the citizen, which is the stage of transparency with citizens.

In the first and fourth stages, the costs are relatively low compared to the second and third stages, while the returns increase gradually according to the stages at the country level as a whole.

The following figure shows the previous stages.

The previous figure shows the stages of the transition starting from the presentation of services and the provision of information by the government to the beneficiary (which is an immature stage), to the stage of services interaction in an integrated manner in order to provide the service to the beneficiary through multiple channels (telephone messaging, online services, single-window services). The result is: increasing the return, reducing the time and cost to implement the required services (Clinton \& Gore Jr, 1993) both to the government or the citizen. In addition it also increases the ease of access to the required information, the availability of obtaining the service at any time, and securing job opportunities, increasing direct and indirect employment opportunities for intermediaries and suppliers to secure implementation requirements of E-government programs.

Based on the previous stages of transition, the expansion of the e-government model in the business sector requires the transition from the stage of commerce to the conduct of business activities electronically, through the stage of electronic commerce, According to the following model.

\section{Challenges of Implementing E-Government Programs in Syria As Opportunities that Can be Used Later}

- The role of e-government in the field of finance and investment: Through the

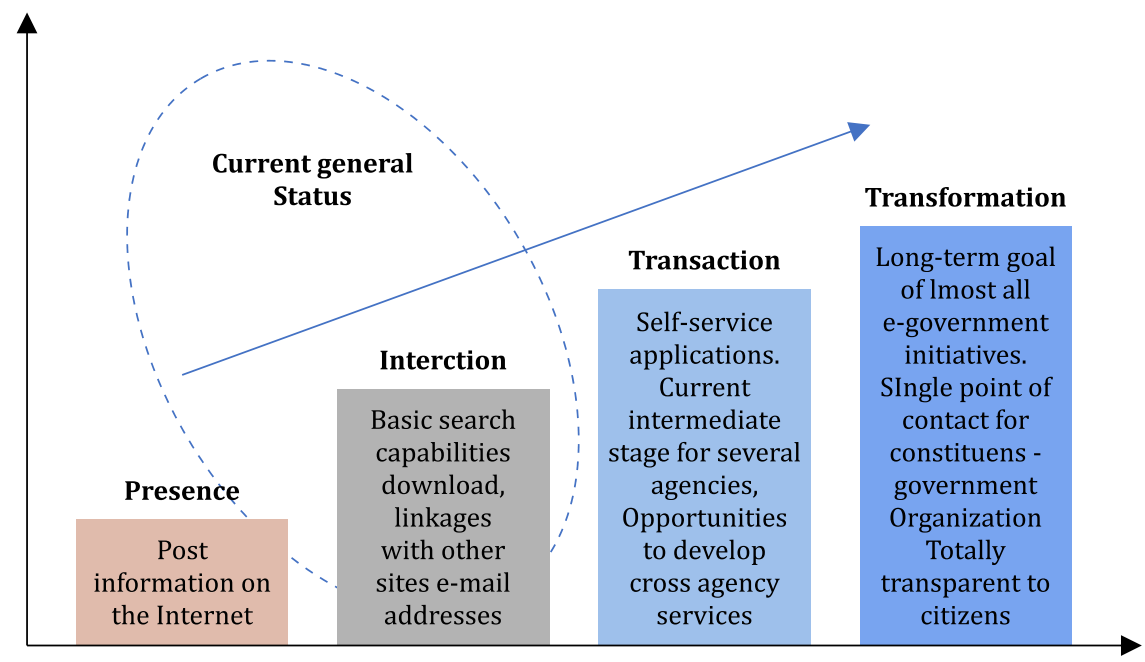

Figure 1. The stages of the development of the e-government project Source: E-government benefits study, National Office for the Information Economy, Australia, April 2003 


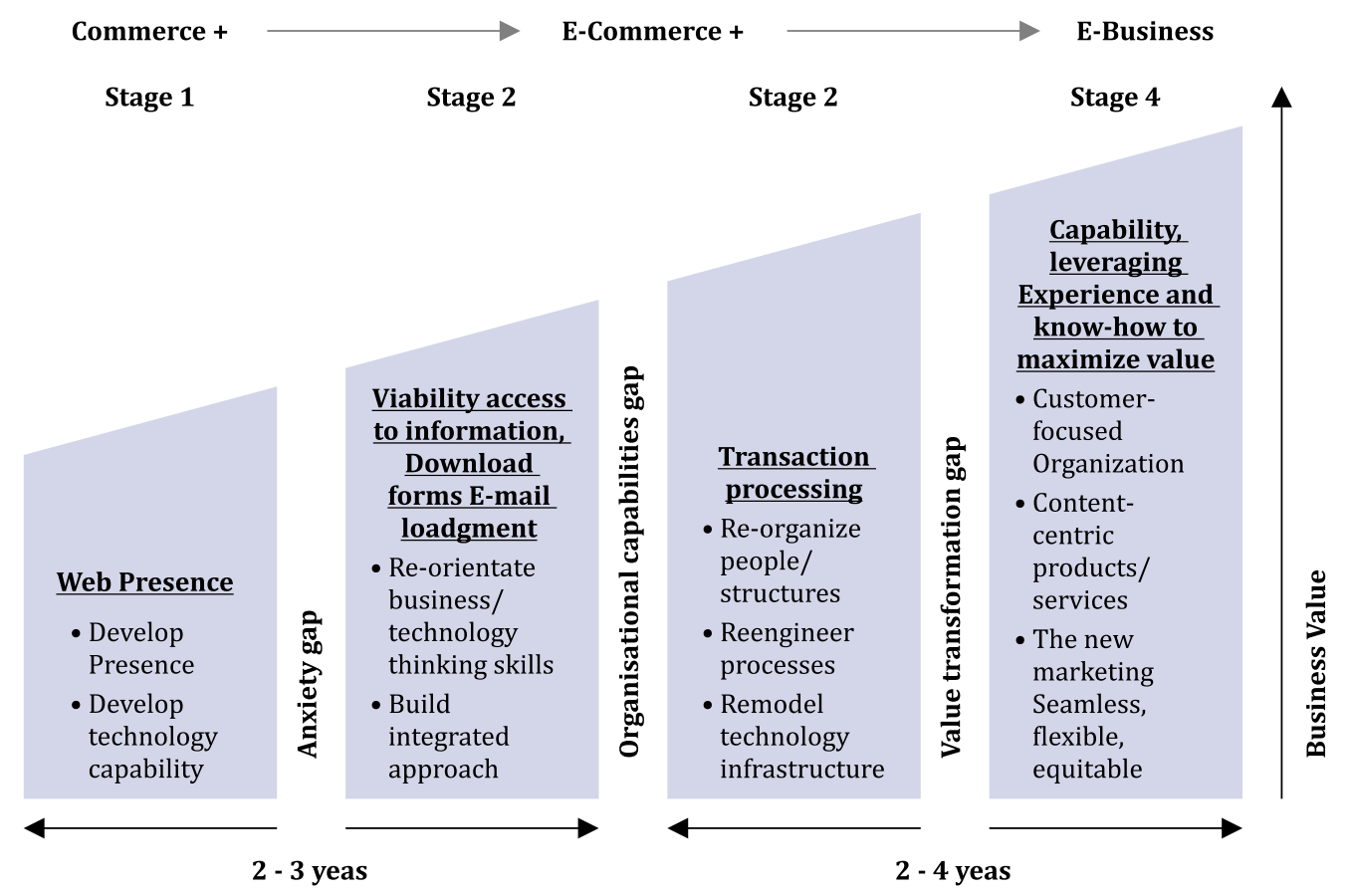

Figure 2. The expansion stages of E-government maturit

Source: E-government benefits study, National Office for the Information Economy, Australia, April 2003

experiences of many countries about the same projects, the study found that the matter requires numerous constant and ongoing investments at the level of the implementing agency, which is the state, and at the same time the lack of financial resources to complete the project and its investment is a major obstacle, both at the country level as a whole or at the level of the entities which implement the projects It cannot be said that this is the only obstacle, but rather a fundamental obstacle that can be overcome by attracting optimal investments to implement the project.

- The relationship of implementing the e-government with the infrastructure of the communications and information technology sector: One of the main factors that determine the level of success of the e-government project is the level of development of the infrastructure of the communications and technology sector, and although this infrastructure is not available in some countries, it was a catalyst for its development, and this is the situation in Syria, who is trying to restructure this vital sector in order to implement the project.

- E-government and its role in the administrative and economic reform process: Together, these reform processes serve as an implementation of the e-government initiative, and various services' qualities will be increased. The most important of which is the increased support for the administrative sector. However, the expansion of the implementation of the program will be hindered by many obstacles regarding the economic, administrative and organizational environment, and it is one of the most important challenges to the maturity of e-government programs in Syria, especially that Syria is on the road to transformation towards a social market economy system, but nevertheless this challenge can be viewed as an opportunity since it concrete helps the process of administrative, economic development and reform, (Syrian Ministry of Communications and Technology SMCT, October, 2009).

- The relationship of implementing the e-government project and the available human resources: In the same context, the re-engineering of the administrative structure 
and the qualitative qualification of human resources in the entities that implement e-government programs can be considered a prerequisite for the success of this program. (Al-Shboul, Rababah, Ghnemat, \& Al-Saqqa, 2014). This is a big challenge when the required human resources are not available and thus it is a real opportunity to develop the curriculum of public administrations and their cadres, as the implementation of e-government programs will be a key factor for interest in continuous training programs in the public sector.

\section{United Nations Survey on the Syrian E-Government Initiative}

In 2010, the United Nations survey on the egovernment implementation in Syria is showing that compared to 2008, it indicated a decline in e-government readiness, taking into account in the evaluation process: the web measurement index, the infrastructure index, and the human capital index. Syria was ranked 119 out of the total 192 countries in 2008, and fell to 134 out of a total of 184 countries in 2010,(UNDP, 2010) as in the following table:

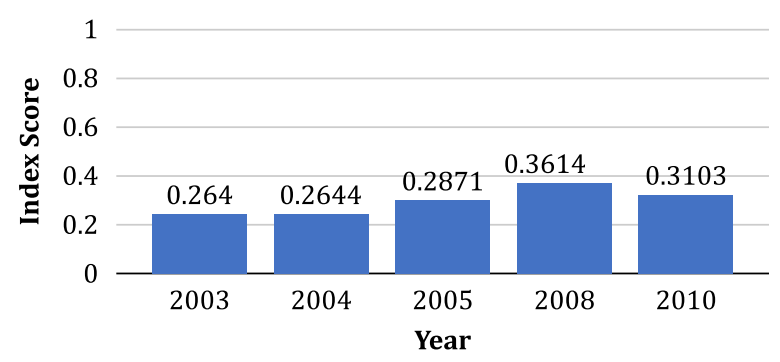

Figure 3. E-government readiness development index in Syria (2003-2010)

Also, there are other indicators that are taken into consideration, such as the E-Participation Index, which reflects the quality of information and the use of services available in the country that aims at citizen participation in public policy-making through e-government programs. Through surveys and comparison between Syria and world countries, we find that Syria's ranking is low (0.014) Compared to the global mean (0.205).(UN, 2010).

\section{Measurement Indicators and Returns Classification}

The most important goals of implementing e-government programs in any country is supporting economic and social development (Al Nagi \& Hamdan, 2009) for the state and the citizen, also at the level of the concerned party or the direct users and beneficiaries. The effects of implementing electronic programs are measured by the extent to which the objectives are achieved through the use of criteria such as: the volume of transactions executed electronically, the speed of responding to inquiries, the number of services provided, the amount of cost to the citizen and the government, compared to the previous one.

Regarding the financial standard, it can be easily calculated by mathematical methods, but other indicators such as: the time standard for service improvement may not be accurate, as some institutions and employees do not care to monitor the time of service delivery and compare it with the financial returns. Therefore, this criterion should not be taken into consideration in addition to the social criteria that achieve excellent benefits if they are well exploited.

Thus, the determinants of implementing egovernment programs are as follows: (Pudjianto, Zo, Ciganek, \& Rho, 2011)

- The nature of the project that the state wants to implement, a profit making, or

Table 1. The e-government readiness index in Syria compared to the global average (2010)

\begin{tabular}{lccccc}
\hline Index & $\begin{array}{c}\text { E-Government } \\
\text { Index }\end{array}$ & $\begin{array}{c}\text { Online Service } \\
\text { Index }\end{array}$ & $\begin{array}{c}\text { Infrastructure } \\
\text { Index }\end{array}$ & $\begin{array}{c}\text { Human Capital } \\
\text { Index }\end{array}$ & $\begin{array}{c}\text { E-Participation } \\
\text { Index }\end{array}$ \\
\hline Syria, Rank 134 & 0.310 & 0.041 & 0.121 & 0.777 & 0.014 \\
\hline World Average & 0.441 & 0.286 & 0.236 & 0.797 & 0.205 \\
\hline
\end{tabular}

Source: UN Global E-Government Survey 2010, E government readiness, http://www2.unpan.org/egovkb/global_reports/10report.htm 
a service project, and what are the financing methods.

- The nature of the service results, are they direct financial returns, or economic returns on the state and society as a whole, or social returns that achieve well-being for citizens in the state.

- Knowing the point of view of the government or the entity that wants to invest in implementing the project.

- The period from the period of preparation and maturity until it reaches the stage of development and continuation.

- The nature of the expected risks and their assessment.

- Estimating the project cost and what are the expected returns.

\section{Analysis of the economic costs and benefits at the macro level}

The National e-government Initiative in Syria, which was launched in 2009 was aimed at automating government institutions according to a comprehensive program of administrative reform that aimed at serving the citizen and economic and social institutions, increasing the effectiveness of government institutions using information and communication technologies in the best way, and reducing administrative costs and rationalizing spending. In addition it is also aimed at raising the efficiency of institutions, improving the level of services, strengthening the principle of participation, and reducing and combating corruption.(SMCT and UNDP, 2010).

This is part of the national strategy for information and communication technologies approved by the government, which includes five initiatives: the national e-government initiative, the national initiative for technical areas, the national initiative for technological centers of excellence, the national initiative for capacity building, and the national initiative for the knowledge society.

Therefore, communication and information technologies are considered a fundamental driver of economic and social development, because it would achieved the development goals at the state level, and the most important of which are:

- Growing state revenue.

- Increasing job opportunities in the local market.

- Improving productivity, enhancing administrative and economic reform, and increasing social welfare.

- Increasing opportunities for exporting telecommunications and information technologies.

The implementation of e-government programs varies from one country to another, because it is linked to multiple factors that make countries compete in implementation, starting from maturity to the stage of implementation, measuring results and integration between the applied government agencies and the administrative structure of the government in an interactive and high-transparency with citizens. The most important of these factors that accelerate the implementation of the e-government program can be mentioned at the level of economic and technical development, the abundance of financial resources, the available human qualifications, but the will to change and achieve the national vision remains the basis for the continued implementation of the e-government initiative.

The costs of the e-government program, including the investment and the current expenditures are covering the following items such as hardware and software, and training, evaluation, monitoring and development. These are important factors for the success of the implementation and the transition from the stage of obtaining information and uploading requests to the stage of complex and interactive processes. However, the availability of financial resources was not the only condition for achieving the goals of e-government, but rather there were many other obstacles such as (Syrian Ministry of Communications and Technology, 2010):

- Computer-related technical and installation 
problems.

- Security and privacy: This requires a special culture of citizens, which must be spread

- Visibility, clarity and follow-up of updates in electronic portals, as many portals suffer from lack of clarity and weakness in design and need an upgrade to available government services.

- Weak user education about the information available electronically, and the inability to access this information sometimes, in addition to the loss of the monitoring factor.

- Expensive computers and limited access to electronic servers and libraries.

By focusing on most of the successful e-government experiences in the rest of the countries, we find that increasing the effectiveness of e-government is through the transition of its programs from the initial stages to the advanced electronic processes adopted by the entities capable of implementing the program. In order to improve the rate of return of profit compared to cost, the product and service must be improved in the first degree.

\section{Benefits and Components of Financial and} Economic Returns from E-Government

\section{Economic benefits at the macro level}

Returns from implementing e-government programs are classified into four levels (Layne \& Lee, 2001):

- The returns of the state or organization that invested in the e-government project, which are represented in reducing financial expenditures, increasing returns, raising efficiency, improving efficiency, and improving service.

- Financial returns for the beneficiaries who are citizens, and they are represented in: reducing the waste of time, saving the cost provided to the state, saving the cost provided to the business sector, providing the service provided to intermediaries.

- Social returns represented in: contributions of government services provided electronically, information that helps in decision-making by citizens and the business sector.
- Contributing to achieving the government's goals, which are represented in: Access to all information and communication technologies, in addition to knowledge of economic data at the macro level.

Components of financial and economic returns from e-government

1. Costs and revenues of the entity implementing the e-government program:

- Direct and indirect costs: which are divided into three basic stages, namely

- The cost of the planning stage, which includes studying the market, formulating the initial vision, determining requirements, connecting the service to the portal.

- Commissioned in the development phase, which includes infrastructure, hardware and equipment, administrative operations and employment, operating, preservation, protection and control software, training in the field of informatics, offices and ancillary equipment, construction and development of sites, network and protection and privacy systems, legal costs.

- Costs for the operation phase, which includes: internal and external communication management, administrative expenses, advertising and marketing, technical support, maintenance and development. (Alshehri \& Drew, 2010).

- Returns:

- Reducing the cost of correspondence with other parties, citizens and companies in the business sectors.

- Reducing the costs of transportation, transportation and correspondence.

- Reducing the burden on the public administration, including the cost of storage and archiving.

- Reduced completion time.

2. Costs and returns for citizens and the business sector benefiting from the egovernment program 
- Assign the beneficiary or user: Computer, software, maintenance, communication, communication costs, recruitment and training.

- Returns: Saving the cost of the consumer and direct financial savings, saving the transportation expenses, save time.

\section{Concerning Indirect Total Returns, (Gupta \&} Jana, 2003)

- Increasing the domestic product.

- Creating direct and indirect job opportunities.

- Increase capital formation.

- Strengthening the administrative structure and administrative reform.

- Increase transparency and participation.

- Increase transparency, trust and access to targeted services.

- Create new opportunities in business activities.

- Creating new job opportunities.

\section{Analysis of the Economic Impact of E-Government Projects in Syria}

Three objectives were defined in the "Syria e-government strategy," which were:

- Supporting the efficiency of the government administration, developing it, simplifying its procedures and reducing the cost of its work.

- Raise the effectiveness of government services.

- Supporting the economic and social development in Syria.

The study attempts to quantify the expected economic impacts and benefits from implementing e-government projects at the national economy level, whereas, information and communication technology achieves important opportunities for developing the public administration that aims to support the economy and society, but it is not necessary for the results to be successful when the initial studies are successful. Especially in the case of the e-government implementation project. Because the matter is also related to the political will, the efficiency of the implementation and the circumstances surrounding the project. It is self-evident that the government studies the economic and social feasibility of e-government projects, but it is not a requirement that these projects succeed if the evaluation results are positive, as the issue is related to political will, the responsiveness of different management levels, the efficiency of implementation and the circumstances surrounding the project. The methodology of this study faces difficulties arising from the specificity of the information, communication and technology sector, and the lack of adequate data to assess the impact of e-government projects prevents access to a clear quantitative statistical model. However, returns can be classified into four levels:(S. S. P. C. UNDP, 2009).

- The returns of the service provider, which are represented in reducing financial expenditures, increasing returns, raising efficiency, improving efficiency, and improving service.

- Financial returns to the beneficiaries: They are represented by the time saved for users, cost savings provided to citizens, cost savings provided to the business sector, service savings provided to intermediaries, and sporadic financial returns.

- Social returns: These are the contributions of government services provided electronically to the quality of life of citizens, the business sector, and intermediaries, which are not easy to measure.

- Contribution to achieving the government's developmental goals: represented in access to information and communication technologies.

\section{Experience of E-Government in European Union Countries}

The reports of the E. government Economics Project of the European Union (EGEP) funded by the European Commission indicated the importance of the economic impact of the European Union's initiative in implementing the e-government program, yet awareness is still weak. 
A similar study was conducted on five countries regarding the economic impact of spending on e-government (France, Germany, Denmark, the Netherlands, and the United Kingdom). In 2004 spending on the e-government initiative in the 25 countries of the Union (11.9 billion euros), excluding spending on the information and communication technology sector, where spending on e-government out of the total public spending on information and communication technology reached $33 \%$ was confirmed. After that, the benefits of e-government initiatives were many, the most important of which are: improving labor productivity for the public sector, providing serious services to beneficiaries with high satisfaction, in addition to saving costs and growing GDP The following figure shows the total public spending on information and communication technology in the European Union countries for 15 countries, during a specific period.

Demand for E-Government Based on the Experiences of the Union Countries

The e-government for internet users is the best form to access its services, which reached $80 \%$ through e-government channels to obtain the required information. Statistics in 2003 also showed that more than $47 \%$ of citizens in the European Union and $57 \%$ of the business sector use programs E-government with an annual growth rate of $30 \%$ annually.

Through an opinion poll to find out the percentage of the beneficiaries' interest in egovernment programs, the following percentages were clarified: $67 \%$ of users want access to download requests, $47 \%$ want integration between agencies, $21 \%$ want to conduct complex transactions, and the majority are interested in health services, taxes and support services.

Some studies have also directed to the importance of covering implementation costs from investment and current expenditures, including hardware and software at all levels, in addition to the costs of training, evaluation, monitoring, and continuous development. Nevertheless, the availability of financial resources was not a sufficient condition to achieve the goals of e-government. Rather, it faced many other technical obstacles such as weak information structure, inadequate



Figure 4. spending on e-government compared to public spending on ICT for the European Union (15 countries, Billion euros, as a percentage, 2002, and 2004)

Source: E. government Economics Project: expenditure study 
computers, weakness in the design of electronic portals that need a permanent upgrade, weak user knowledge of what is available in e-government programs, inability to access information and lack of knowledge of costs, in addition to the loss of the monitoring factor that made the user feel unsafe, in addition to the user's fear of privacy leak.

\section{Benefits of e-government according to the experiences of the Union countries}

The study summarizes the following returns based on an analysis of the results of the experiences of European Union countries for all the programs that we referred to previously, taking into account the lack of digital data and the fact that there are some programs who are still in the beginning of the implementation phase. Some points are recorded as follows:

- The services provided to citizens have improved, as the detailed study of 38 programs showed that the services provided to citizens and the social welfare have improved, which is a basic goal, and in the opinion poll, the statistics confirmed that more than $80 \%$ of citizens assert that the e-government has a moderate impact on the social return.

- Reduction in consumer expenditures based on the speed of obtaining the required service.

- Less waiting time, reducing service time and greater service quality.

- The decrease in direct costs based on the citizens' opinion poll, where $45 \%$ of users noticed that they saved through the e-government, and $10 \%$ of citizens and $23 \%$ of the business sector and intermediaries were able to estimate the real savings for each operation, which amounted to $\$ 25$ per operation.

- As for the entities that implemented the e-government project, they were also able to achieve savings and were measured through the speed of operations and the low cost of administrators, as the study of programs (169 implemented programs) by 38 entities indicates that these programs have achieved a saving equivalent to $\$ 1.1$ billion during the period (1998-2004), in addition to the social returns assessed by the citizens.

The following figure shows revenues from e-government programs according to the nature of the service.

\section{Study case: The Commercial Bank of Syria (CBS): the electronic work system and its obstacles}

The Commercial Bank of Syria is the first governmental institution to implement the e-mail program. The bank started the automation project in 2001, stalled a little, and then the implementation actually started in 2007 and is now in the stage of development and expansion. The bank fully adopts the electronic communication system between the public administration in the capital Damascus and the branches in all the Syrian governorates, which number 70 commercial branches and service offices, in addition to its services in electronic payment. The most important justification for choosing the Syrian Commercial Bank as a sample to implement e-government in Syria is its wide geographical spread in Syria, the nature of its

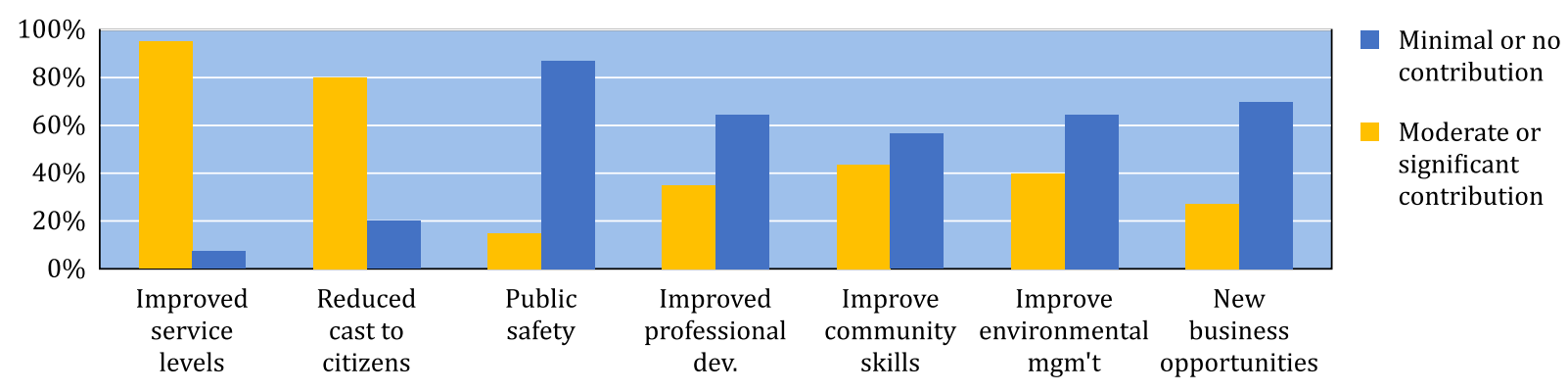

Figure 5. Revenues from e-government programs according to the nature of the service Source: E-government benefits study, National Office for the Information Economy, Australia, April 2003 
service work that a wide range of Syrian citizens need, the nature of the great competition between financial sectors, the possibility of exporting the experience to the rest of the government sectors .(Syrian State Planning Commission, 2009)

The Mechanism Working at the CBS, Before and After Implementing the E-Government System

The Commercial Bank of Syria started the communication system between the bank's branches and the central administration completely on paper through administrators and correspondents who send daily mail to and from the bank, or send by fax and phone, in this way a great effort was wasted in addition to the accumulation of high mail expenses.

In 2002, the bank adopted the "MYSYS" system as an alternative to the paper system, and it is currently undergoing continuous development stages. In conjunction with the electronic credit systems, which became ready in 2008, and correspondence between managers and employees began by e-mail in two ways: internal communication, where the bank does not use any paper transactions in its internal operations except rarely, as the levels of administration, directorates, branches, and divisions continue vertically and horizontally. According to the scope of authority, the second method is electronic communication between the bank and the public authorities, which is between the bank's management and its branches in the rest of the Syrian governorates, also the correspondence between the bank and the Ministry of Finance, between the commercial bank and the Central Bank of Syria, and between the bank and the ministries and other institutions.

\section{E-Government Obstacles in CBS}

Before and after implementing the e-government program, the commercial bank faced many obstacles, some of which it was able to overcome and is still in the stage of maturity now. The study points to the most important obstacles: - The government has not approved the electronic signature with all its powers yet, as this is not one of the bank's powers but the government's, and this is an obstacle to the development of the business sector and interactive messaging between the bank and the beneficiaries. This is also the reason for delaying the completion of banking transactions, and delaying obtaining information and executing banking operations directly, and regardless of where the customer is geographically located inside Syria.

- Expanding the network, developing equipment, investing offers, and legally implementing them without bureaucratic obstacles.

- Despite the bank's implementation of the continuous work system, there are difficulties hindering the spread and generalization of the concept of e-government, especially in its dealings with public and private entities alike, which can be included within the concept of institutional work culture. Nevertheless, the success of this experiment constitutes an incentive for its application in other public bodies.

- Following up on the rehabilitation and training programs on the current system and its updates for employees.

- Program development is still slow, and new programs must be adopted to be more in line with modern systems.

- The quality of the network in many times constitutes an obstacle for the customer to obtain the required service at the highest speed.

\section{RESEARCH METHOD}

This research paper relied on an analytical methodology based on analysing the economic impact of implementing the e-government project and analysing the return/cost. In addition, it is also measuring the value of electronic services, where a methodology was built to analyze costs and study the expected financial and economic benefits of the above mentioned projects within the e-government strategy and determine their economic feasibility. 


\section{Data collection}

The data needed for the paper were collected by relying mainly on official government sources and reports in Syria, which formulated the egovernment initiative as it provides a preliminary and theoretical approach to achieving the government's goals by spreading and raising awareness about adopting the principle of e-government.

The study mentions the most important of these official reports and periodicals, which the study focused on as a tool in the analysis:

- The general framework of the e-government initiative in Syria.

- The general principles and concepts for implementing the e-government project.

- The e-government strategy in Syria (vision and objectives).

- The e-government strategy in Syria (programs).

- E-Government Development and Modernization Project: Monitoring and Evaluation Framework.

- United Nations survey of the e-government project.

\section{RESULT AND DISCUSSION}

Some previous researchers referred to the egovernment system as that it is only a technical program only, but in fact, it turned out to be a prerequisite in the process of administrative development and reform, because it is a method, a work culture, and a way to facilitate transactions between citizens and government institutions.

E-government is one of the important topics that has recently getting increased attention by most countries, especially in light of the difficult economic conditions currently facing the world. This is because it connects and processes information through communication networks, and from this standpoint this study aimed to build an analytical vision about the financial benefits, and the expected economic benefits as a result of implementing the e-government project in Syria, determining its feasibility, indicating the expected effects on the overall economy, and analyzing the return / cost of implementing e-government, in addition to measuring the value of electronic services.

In order to achieve this, the researcher built a methodology to analyze the financial and economic costs and benefits of the projects mentioned in the e-government strategy and determine their feasibility. The study used the secondary data available in the government sources and reports that formulated the e-government initiative.

The study presented the experience of the Syrian Commercial Bank by evaluating the electronic work system, as this bank was chosen because it is the most widespread bank in all parts of Syria. It was found through the study sample that the application of e-government faces many obstacles, including those related to the economic, administrative and organizational environment, which can be considered one of the most important challenges to the maturity of e-government programs applied especially in a country like Syria that is moving towards transformation and adopting the social market economy approach. These obstacles are an opportunity to help in the process of administrative and economic development and reform.

Accordingly, the study presented the results and experiences of implementing e-government in several countries, including the e-government experience in the European Union, as it was found that e-government initiatives improve labor productivity for the public sector, provide feasible services, save costs, and grow the gross domestic product.

\section{CONCLUSION AND RECOMMENDATION}

The paper concluded that the application of e-government will have a positive impact on the economy of Syria, as the returns from the implementation of the e-government are the returns of the entity that implemented the program and are represented by reducing financial expenditures, increasing returns, 
raising efficiency, increasing financial returns for the beneficiaries by saving time and saving costs for citizens, and also saving the cost to the business sector and middlemen. In addition it also shows social returns, which are represented by the contributions of government services provided electronically with high quality, the contribution to achieving the government's objectives, which are represented in the large access to information, in addition it also improves the quality of information and the government's openness, which enhances the degree of transparency.

The financial and economic returns from egovernment and its programs can be measured through several indicators, which are the return on investment, the rate of return to cost, and the net present value, in addition to indirect total returns such as (increasing the GDP, creating direct and indirect job opportunities, increasing the capital formation, strengthening the administrative structure and administrative reform, increasing transparency and participation).

The most important thing is the interest in administrative development in addition to the interest in the return on project criterion.

\section{Limitations and Future Research}

Syria decided to move towards economic advancement and the pursuit of success after its political and economic suffering since 2011. This will require Syria government to re-engineer the infrastructure and administration of all official bodies that deal with the beneficiaries, through the application of e-government within most of its institutions. The limitations of this study is the lack of the explanatory approach to statistically analyze the impact of independent variables toward dependent variables applied to this specific research. So based on these limitations, this study suggest for a future research of conducting analytical future studies based on statistical analysis to show the impact of the application of e-government on the income of state institutions, as well as conducting studies to know the effect of e-government implementation on the profitability of companies or its impact on organizational performance or on the level of employee performance.

\section{Managerial Implications}

The following recommendations are based on the economic impact that was previously presented in the study, and in light of the positive results of the practical situation in the Commercial Bank of Syria, and taking into account all the obstacles that have faced and are still facing the implementation of the e-government program. It also takes into account that Syria is in the beginning stages of implementing e-government programs compared to the countries of the Middle East, and the fact that Syria's status in the e-government readiness index has declined, and the gap between the current situation in Syria with other Middle East countries, and also the gap between the organizational capabilities:

- The concerned authorities in Syria must proceed to implement e-government in various sectors، especially the economic' in the various aspects of the country, which will contribute to rationalizing the decisions taken.

- The necessity of re-engineering the infrastructure and administration in institutions that implement e-government programs.

- Increase training and technical qualification of workers in institutions concerned with software application، especially in light of the current accelerating developments.

- Building a clear quantitative statistical model that links the relationship between the implementation of e-government programs with the direct effects on the overall economy.

Regarding the recommendations related to the e-government obstacles facing the Syrian bank, the researcher recommends the following:

- Adoption of the e-mail signature by the government to assist the user in obtaining the required information and services as quickly as possible, and in order to assist the user in implementing banking operations 
directly and interactively, regardless of his geographical location in Syria.

- Continuously developing existing programs and adopting new programs.

- Expanding the network، developing equipment، investing offers، and legally implementing them at the required speed without bureaucratic obstacles.

- Following up the rehabilitation and training programs on the current system.

- Improving the quality of the network that deals with e-government.

\section{REFEREN CES}

Al-Shboul, M., Rababah, O., Ghnemat, R., \& Al-Saqqa, S. (2014). Challenges and factors affecting the implementation of e-government in Jordan. Journal of Software Engineering and Applications, $7(13), 1111$.

Al Nagi, E., \& Hamdan, M. (2009). Computerization and e-Government implementation in Jordan: Challenges, obstacles and successes. Government information quarterly, 26(4), 577-583.

Alshehri, M., \& Drew, S. (2010). E-government fundamentals. Paper presented at the IADIS international conference ICT, society and human beings.

Clinton, W. J., \& Gore Jr, A. (1993). Technology for America's economic growth, a new direction to build economic strength: EXECUTIVE OFFICE OF THE PRESIDENT WASHINGTON DC.

Gupta, M. P., \& Jana, D. (2003). E-government evaluation: A framework and case study. Government information quarterly, 20(4), 365-387.

Krishnan, S., Teo, T. S., \& Lymm, J. (2017). Determinants of electronic participation and electronic government maturity: Insights from cross-country data. International Journal of Information Management, 37(4), 297-312.

Layne, K., \& Lee, J. (2001). Developing fully functional E-government: A four stage model. Government information quarterly, 18(2), 122-136.

Palvia, S. C. J., \& Sharma, S. S. (2007). E-government and e-governance: definitions/domain framework and status around the world. Paper presented at the International Conference on E-governance.

Pudjianto, B., Zo, H., Ciganek, A. P., \& Rho, J. J. (2011). Determinants of e-government assimilation in Indonesia: An empirical investigation using a TOE framework. Asia Pacific Journal of Information Systems, 21(1), 49-80.

SMCT and UNDP. (2010). The General Framework for the E-Government Initiative in Syria, Government Services Development and Modernization Project, Government Strategy, Syrian Ministry of Communications and Technology in cooperation with the United Nations Development Program UNDP.

Syrian Ministry of Communications and Technology, S. (2010). The general framework of the e-government initiative in Syria, Syrian Ministry of Communications and Technology.

Syrian Ministry of Communications and Technology SMCT. (October, 2009). The e-government strategy in Syria (vision and objectives), Government Services Development and Modernization Project, Syrian Ministry of Communications and Technology in cooperation with the United Nations Development Program UNDP.

Syrian State Planning Commission. ( 2009). Government Services Development and Modernization Project - Government Strategy - Part One, General Principles and Concepts of E-Government, Syrian State Planning Commission in cooperation with the United Nations Development Program UNDP. 
UN. (2010). Global E-Government Survey , http://www2.unpan.org/egovkb/global_reports/10report.htm UNDP. (2010). United Nations survey of the e-government project, Syria, Syrian State Planning Commission. UNDP, S. S. P. C. (2009). E-Government Strategy in Syria, Government Services Development and Modernization Project - Government Strategy, Syrian State Planning Commission in cooperation with the United Nations Development Program UNDP.

United Nations Development Program UNDP. (2011). E-Government Development and Modernization Project: Monitoring and Evaluation Framework. 